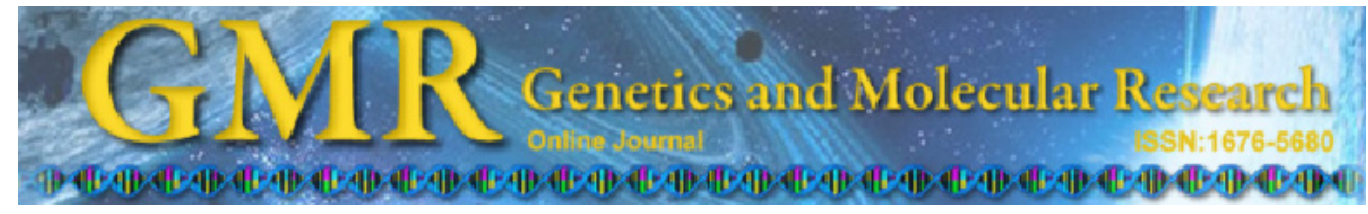

\title{
Estimation of taurindicine hybridization of American Zebu cattle in Brazil
}

\author{
P. Ripamonte ${ }^{1}$, M. Baccaglini ${ }^{1}$, A.S.M. Cesar ${ }^{1}$, L.G.G. Figueiredo ${ }^{1}$, \\ J.C.C. Balieiro ${ }^{1}$, A.R. Caetano ${ }^{2}$ and F.V. Meirelles ${ }^{1}$ \\ ${ }^{1}$ Departamento de Ciências Básicas, \\ Faculdade de Zootecnia e Engenharia de Alimentos, \\ Universidade de São Paulo, Pirassununga, SP, Brasil \\ ${ }^{2}$ Embrapa Recursos Genéticos e Biotecnologia, Brasília, DF, Brasil \\ Corresponding author: F.V. Meirelles \\ E-mail: meirellf@usp.br
}

Genet. Mol. Res. 11 (1): 393-403 (2012)

Received January 31, 2011

Accepted November 2, 2011

Published February 17, 2012

DOI http://dx.doi.org/10.4238/2012.February.17.1

\begin{abstract}
Our objective was to estimate Bos primigenius taurus introgression in American Zebu cattle. One hundred and four American Zebu (Nellore) cattle were submitted to mtDNA, microsatellite and satellite analysis. Twenty-three alleles were detected in microsatellite analysis, averaging $4.6 \pm 1.82$ /locus. Variance component comparisons of microsatellite allele sizes allowed the construction of two clusters separating taurus and indicus. No significant variation was observed when indicus and taurus mtDNA were compared. Three possible genotypes of $1711 \mathrm{~b}$ satellite DNA were identified. All European animals showed the same restriction pattern, suggesting a Zebu-specific restriction pattern. The frequencies of $B$. primigenius indicus-specific microsatellite alleles and $1711 \mathrm{~b}$ satellite DNA restriction patterns lead to an estimate of $14 \%$ taurine contribution in purebred Nellore.
\end{abstract}

Key words: Cattle; taurus; indicus; mtDNA; Microsatellites; 1711 b satellite 


\section{INTRODUCTION}

Domestic cattle breeds have been separated into two groups, taurine (Bos primigenius taurus) and zebuine (Bos primigenius indicus), according to center of origin (i.e., Western Europe/Northern Africa and India, respectively), which has been corroborated by morphological, biochemical, cytogenetic, and molecular characteristics (Loftus et al., 1994a,b; Bradley et al., 1996; MacHugh et al., 1997; Liu et al., 2003; Mannen et al., 2004). Despite the observed physical differences, these groups are considered to be two subspecies due to offspring fertility (Kieffer and Cartwright, 1968; Manwell and Baker, 1980; MacHugh et al., 1997; Bradley and Cunningham, 1999).

A matrilineal taurine contribution has been reported in Zebu cattle since its introduction to the American continent. According to historical data and mitochondrial genome studies (Loftus et al., 1994a,b; Edwards et al., 2000), the majority of American Zebu cattle breeds were derived from backcrossing European B. primigenius taurus females and Asiatic $B$. primigenius indicus bulls. This hybridization was confirmed when the major contribution of the B. primigenius taurus mitochondrial genome in these animals was analyzed (Meirelles et al., 1999).

Ever since the $B$. primigenius taurus maternal line contribution was assessed in the American Zebu cattle breeds, the question has been how much of the B. primigenius taurus genes are fixed or segregating in zebuine animals. Several nuclear markers can be used to follow the taurine and zebuine genomic segregation in backcrossed populations. Microsatellite alleles specific to Indian zebuine, African taurine and European taurine breeds have been identified by several authors (MacHugh et al., 1997; Loftus et al., 1999; Hanotte et al., 2000; Edwards et al., 2000; Ibeagha-Awemu et al., 2004), and significant differences in the alelle frequencies among cattle breeds from Europe, Africa and India have also been observed. Zebuspecific alleles emphasize the divergence between B. primigenius indicus and B. primigenius taurus genomes (MacHugh et al., 1997).

According to genetic distances showed by Bradley et al. (1998), African bovine populations possess hybrid origin. B. primigenius indicus and B. primigenius taurus, both show taurine-specific mitochondrial DNA, and microsatellite frequency indicates African Zebu's hybrid origin.

The cattle nuclear genome contains several centromeric satellite DNA distributed in different loci and it was observed that the relative amounts of satellites and their sequence variants may fluctuate considerably (Nijman and Lenstra, 2001). Recently, a 1711b centromeric satellite DNA restriction pattern suggestive of taurindicine hybridization of African populations was described (Nijman et al., 1999). This satellite DNA represents $7.1 \%$ of the bovine genome (Macaya et al., 1978). Variation in restriction patterns due to the relative proportion of $B$. primigenius taurus and B. primigenius indicus polymorphisms may contribute to estimating the taurine contribution to American Zebu breeds.

However, American Zebu cattle were clustered into two groups according to mtDNA: descendents of purebred of imported origin (POI) animals with $B$. primigenius indicus mtDNA and purebred origin (PO) with B. primigenius taurus mtDNA (Meirelles et al., 1999). Nellore POI animals were used in our studies as controls. They contain mainly $B$. primigenius indicus genes and can be used to estimate the rate of taurus/indicus hybridization. The frequencies of B. primigenius taurus-specific haplotypes can be used as indicative of taurine genome contri- 
bution. The main purpose of the present study was to investigate the contribution of taurine genes to the Zebu American cattle breeds.

\section{MATERIAL AND METHODS}

\section{Samples and DNA isolation}

Genomic DNA was extracted from white blood cells according to standard procedures (Sambrook and Russell, 2001) from blood samples from a total of 169 animals of the following breeds: Nellore $(\mathrm{N}=104)$, Brazilian Caracu $(\mathrm{N}=48)$, Holstein $(\mathrm{N}=5)$, Limousin $(\mathrm{N}=4)$, Simmental $(\mathrm{N}=4)$, Charolais $(\mathrm{N}=1)$, Aberdeen Angus $(\mathrm{N}=1)$, Ayrshire $(\mathrm{N}=1)$, and Piedmontese $(\mathrm{N}=1)$. DNA samples from taurine breeds were obtained from the Roslin Institute (2001), Edinburgh, Scotland, UK (http://www.projects.roslin.ac.uk/) and used as allelic standards.

\section{Mitochondrial DNA PCR-RFLP}

A subunit of the mitochondrial ND5 gene (nucleotide 11770 to 12525 , according to Anderson et al., 1982) was amplified with primers 5'-CCCAACGAGGAAAATATACC-3' and 5'-AACCGCAAACAACCTCTTCC-3'. PCRs were carried out in a total of $25 \mu \mathrm{L}$ using 1.5 $\mathrm{mM} \mathrm{MgCl}{ }_{2}$ for 35 cycles of $30 \mathrm{~s}$ at $94^{\circ} \mathrm{C}, 45 \mathrm{~s}$ at $58^{\circ} \mathrm{C}$ and $90 \mathrm{~s}$ at $72^{\circ} \mathrm{C}$. Amplified fragments were digested with endonuclease HindIII, for $3 \mathrm{~h}$ at $37^{\circ} \mathrm{C}$, in PCR buffer and run on $1.5 \%$ agarose gel stained with ethidium bromide. The presence of the HindIII restriction site is indicative of B. taurus mitochondrial DNA origin (Meirelles et al., 1999).

\section{Microsatellite analysis}

Each DNA sample was genotyped with five dinucleotide microsatellite markers: HEL1, HEL9 (Kaukinen and Varvio, 1993), ETH225 (Steffen et al., 1993), INRA063 (Vaiman et al., 1994), and ILSTS005 (Brezinsky et al., 1993). PCRs were carried out using 50 ng DNA template in a $25-\mu \mathrm{L}$ total reaction volume under the following conditions: 200 $\mathrm{mM}$ dNTPs, $3.5 \mathrm{mM} \mathrm{MgCl}, 10 \mu \mathrm{M}$ of each primer, $1.25 \mathrm{U}$ Taq polymerase and 35 cycles of $30 \mathrm{~s}$ at $94^{\circ} \mathrm{C}, 45 \mathrm{~s}$ at $50-58^{\circ} \mathrm{C}$ and $45 \mathrm{~s}$ at $72^{\circ} \mathrm{C}$. Reverse primers were fluorescently labeled and PCR products were analyzed by electrophoresis on $6.5 \%$ denaturing polyacrylamide gels. Fragments were visualized through laser excitation in an FLA3000 (Fuji Film, Tokyo, Japan). Bands were analyzed and their size assessed by the Science Lab-Image Gauge software (Fuji Film).

\section{Satellite 1711b DNA PCR-RFLP}

An 875-bp fragment from bovine satellite 1711b DNA (Nijman and Lenstra, 2001) was amplified in Nellore, Caracu and European taurine breeds using $10 \mu \mathrm{M}$ of a forward primer 5'-CCC ACT ACC TCT CTC TGA AAA-3' and reverse primer 5'-TGA TCC AGG GTA TTC GAA GGA-3', $3.5 \mathrm{mM} \mathrm{MgCl}, 1.25 \mathrm{U}$ Taq polymerase and $200 \mathrm{mM}$ dNTPs.

DNA samples from a total of six animals from Holstein, Nellore harboring B. taurus 
mtDNA and Nellore harboring $B$. indicus mtDNA were amplified by PCR as described before. The amplicons were purified with a QIAEX II kit (QIAGEN Inc., USA) and sequenced with BigDye $^{\mathrm{TM}}$ terminator chemistry (Applied Biosystems, USA), in an ABI Prism 377 DNA sequencer (Applied Biosystems).

Sequencing results from taurine and zebuine samples revealed a subspecies-specific $M s p$ I restriction site (i.e., restriction pattern B: 524 and 121 restriction sites present in taurine samples and restriction pattern A and/or AB: 121 and/or 524 restriction sites present in Nellore samples), which was selected for the screening process. Digestions of the PCRamplified fragments were carried out for $3 \mathrm{~h}$ at $37^{\circ} \mathrm{C}$ and fragments were visualized after electrophoresis on ethidium bromide-stained $2 \%$ agarose gels. The estimate of taurine/zebuine contribution was done by direct counting of animals with satellite DNA restriction patterns $\mathrm{A}, \mathrm{B}$ or $\mathrm{AB}$.

\section{Statistical analysis}

\section{Microsatellites}

Allele frequencies were estimated by direct counting and compared by the chi-square test. The observed heterozygosity $\left(H_{\mathrm{O}}\right)$ and unbiased gene diversity $\left(H_{\mathrm{E}}\right)$ for Nellore with taurus mtDNA, Nellore with indicus mtDNA and European breeds were calculated according to Nei (1987). The deviation from Hardy-Weinberg equilibrium (HWE) was estimated using GENEPOP Package v.3.4 (Raymond and Rousset, 1995).

Admix software (Chakraborty, 1985) was used to estimate the genetic admixture proportions from parental populations (European breeds and Nellore mtDNA indicus) on hybrid population (Nellore mtDNA taurus) using allele frequencies. European breed allele frequencies (Aberdeen Angus, Ayrshire, Charolais, Simmental, Holstein) were obtained from the Cattle Diversity Database maintained at the Roslin Institute (2001).

\section{Satellites}

Allele frequencies were analyzed using the generalized linear model methodology (Nelder and Wedderburn, 1972) and the SAS GENMOD procedure (Statistical Analysis System, version 8.02; SAS, 2004). We assumed that the response variable (number of animals with satellite DNA restriction patterns A, B or AB) would have followed the Poisson distribution, which prompted us to use a nonlinear link function, $\eta=\log (\mu)$. The systematic part of the model considered, with a linear predictor, the restriction pattern effects nested in breeds, together with constant $(\mu)$ and random residual effects $\left(\varepsilon_{k}\right)$.

\section{RESULTS}

\section{Mitochondrial DNA}

A total of $63 \%$ of the purebred Nellore samples analyzed showed B. primigenius taurus mtDNA. Figure 1 shows the restriction pattern obtained for $B$. primigenius indicus and $B$. primigenius taurus breeds. 


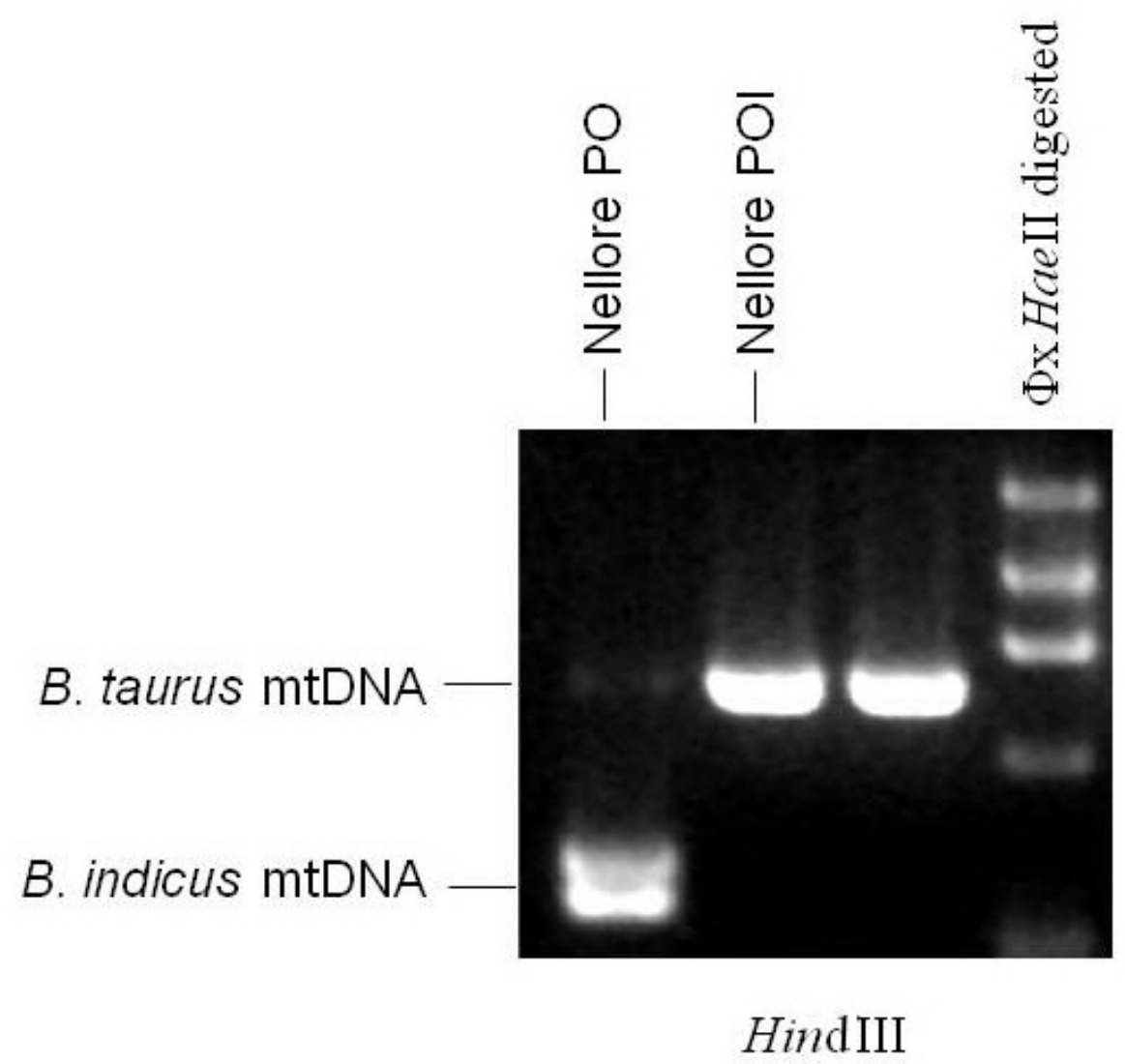

Figure 1. Differentiation of Bos primigenius taurus and B. primigenius indicus by PCR-RFLP analysis of subunit of the mitochondrial ND5 gene (adapted from Meirelles et al., 1999). PO = purebred origin; POI = purebred of imported origin.

\section{Microsatellite analysis}

Based on the mtDNA results obtained in the presence of HindIII assay, Nellore animals harboring taurus mtDNA $(\mathrm{N}=65)$ and Nellore harboring indicus $\mathrm{mtDNA}(\mathrm{N}=39)$ were compared with European breeds. A total of 23 alleles were detected across 5 microsatellite markers, which represents a mean number of alleles (MNA) of $4.6 \pm 1.82$ per locus. Estimated allele frequencies are shown in Table 1. $H_{\mathrm{E}}$ and $H_{\mathrm{O}}$ heterozygosities are shown in Table 2. No significant differences were found in values obtained in either Nellore group (data not shown). The INRA063 locus showed a significant deviation from HWE. The most polymorphic locus was ETH225, with 7 alleles. Although no mean allele frequency was observed between Nellore taurus and indicus groups, some alleles were found more frequently either in groups of animals containing indicus or taurus mtDNA. For instance, with the ETH225 most of Nellore indicus mtDNA showed 147- and 159-bp alleles, whereas Nellore taurus mtDNA only showed 143- and 161-bp alleles. 
P. Ripamonte et al.

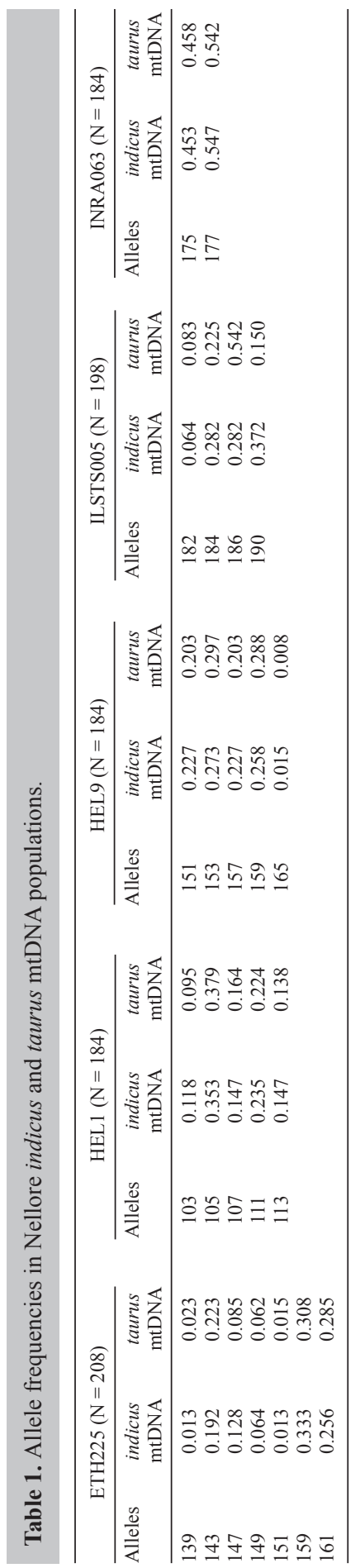


Table 2. Mean number of alleles (MNA), Nei's unbiased gene diversity $\left(H_{\mathrm{E}}\right)$ and average observed heterozygosity $\left(H_{\mathrm{O}}\right)$ for Nellore taurus mtDNA, Nellore indicus mtDNA and mtDNA European taurine pattern.

\begin{tabular}{lcccc}
\hline Populations & MNA $\pm \mathrm{SD}$ & Sample size & $H_{\mathrm{E}}(\mathrm{SD})$ & $H_{\mathrm{O}}(\mathrm{SD})$ \\
\hline Taurine pattern & $3.60 \pm 1.67$ & 7 & $0.516(0.111)$ & $0.875(0.084)$ \\
indicus mtDNA & $4.60 \pm 1.82$ & 39 & $0.705(0.052)$ & $0.846(0.035)$ \\
taurus mtDNA & $4.60 \pm 1.82$ & 65 & $0.682(0.051)$ & $0.800(0.026)$ \\
\hline
\end{tabular}

Allele frequencies were used to estimate the genetic admixture proportions from parental populations (European breeds and Nellore mtDNA indicus) on the hybrid population (Nellore mtDNA taurus; Table 3). The results indicate that these animals contain an average of $14.2 \%$ of the residual taurine genome.

Table 3. Admixture proportions from parental populations in Nellore mtDNA taurus hybrid population.

\begin{tabular}{lr}
\hline Populations & \multicolumn{1}{c}{ \pm SD } \\
\hline Aberdeen Angus & $0.0065 \pm 0.0438$ \\
Ayrshire & $-0.0426 \pm 0.0421$ \\
Charolais & $0.0929 \pm 0.1453$ \\
Simmental & $0.0799 \pm 0.0502$ \\
Holstein & $0.0052 \pm 0.1324$ \\
Nellore mtDNA indicus & $0.8581 \pm 0.0000$ \\
\hline
\end{tabular}

\section{Satellite 1711b DNA}

Analysis of the MspI restriction pattern of the PCR-amplified 1711b satellite DNA revealed two alleles: one restriction site at position 121 (allele A) and two sites at positions 524 and 121 also homogeneously distributed (allele B). All samples from taurine breeds contained $100 \%$ of the B allele. Some Nelore and Caracu samples contained $100 \%$ of the A allele, while the remaining samples contained varying ratios of the $\mathrm{A}$ and $\mathrm{B}$ alleles, due to uneven number of satellite DNA copies of A and B patterns, respectively, in the same animal (Figure 2). The restriction site described in GenBank and by Streeck (1982) is only assumed to be at restriction site position 524 for MspI. Our sequencing data and RFLP analysis showed the absence of this site in some B. primigenius indicus sequences and the presence of this additional site at position 121. This is in agreement with Nijman and Lenstra (2001) with regard to Zebu and European breeds.

Frequencies comparing restriction patterns $\mathrm{A}, \mathrm{B}$ and $\mathrm{AB}$ in Nellore, Caracu and European breeds are shown in Table 4 and the statistical analysis revealed that there are no differences between Nellore harboring indicus mtDNA and Nellore harboring taurus mtDNA for the A pattern frequency. A significant difference $(\mathrm{P}<0.05)$ was found between Nellore harboring indicus mtDNA and Nellore harboring taurus mtDNA in the AB pattern frequency, probably originated by the variable number of copies of A and B patterns, simultaneously. Significant differences were also found for the B pattern comparing Caracu and Nellore harboring taurus mtDNA, Caracu and Nellore harboring indicus mtDNA and Caracu and European. As mentioned before European breeds showed only the B pattern and although no differences had been observed in the frequencies of the B restriction pattern between the two Nellore populations, those animals harboring mtDNA taurus showed a high frequency of the B pattern. 

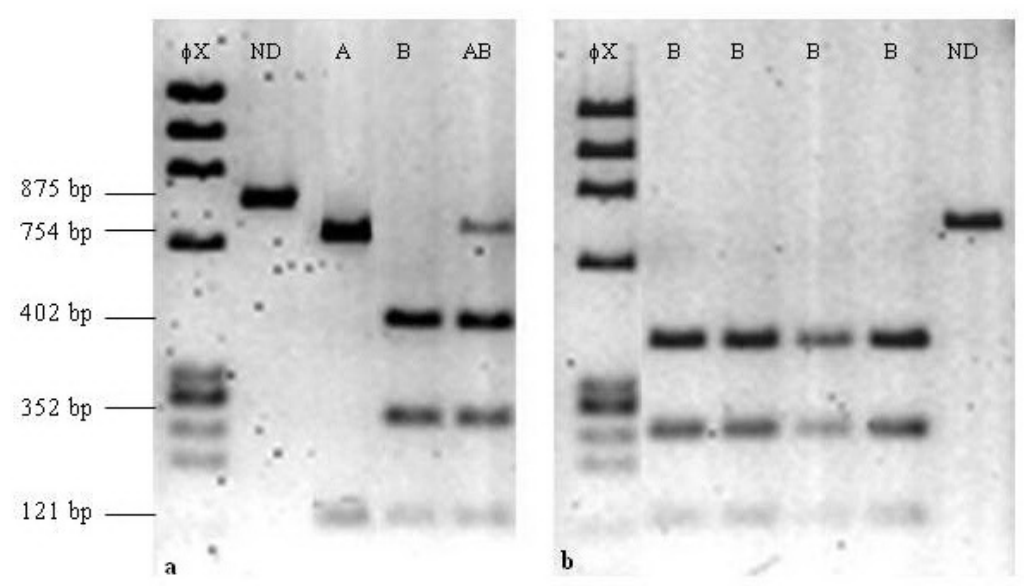

Figure 2. $M s p I$ restriction site of $1711 \mathrm{~b}$ satellite DNA from Nellore (a) and European breeds (b). Lane $N D=$ Nondigested fragment; lane $A=$ one restriction site at position 121 homogeneously distributed in all satellite DNA copies; lane $B=$ two sites at positions 524 and 121 also homogeneously distributed; lane $A B=$ the two restriction sites heterogeneously distributed. Lane $ø X=$ Molecular marker.

Table 4. Chi-square values for Nellore mtDNA taurus (t), Nellore mtDNA indicus (i) and European pattern.

\begin{tabular}{llrr}
\hline Restriction pattern & Breeds & Chi-square & P \\
\hline A & Caracu x Nellore mtDNA i & 1.51 & 0.2195 \\
& Caracu x Nellore mtDNA t & 3.35 & 0.0674 \\
& Nellore mtDNA i x Nellore mtDNA i & 0.52 & 0.4692 \\
AB & Caracu x Nellore mtDNA i & 1.47 & 0.2257 \\
& Caracu x Nellore mtDNA t & 0.71 & 0.3996 \\
& Nellore mtDNA i x Nellore mtDNA t & 3.96 & 0.0467 \\
B & Caracu x Nellore mtDNA i & 10.67 & 0.0011 \\
& Caracu x Nellore mtDNA t & 3.96 & 0.0465 \\
& European x Caracu & 3.96 & 0.0465 \\
& European x Nellore mtDNA i & 2.38 & 0.1229 \\
& European x Nellore mtDNA t & 0.00 & 1.0000 \\
& Nellore mtDNA i x Nellore mtDNA i & 2.38 & 0.1229 \\
\hline
\end{tabular}

\section{DISCUSSION}

In this study, we used autosomal microsatellite and satellite markers to estimate the taurine participation in American Zebu breeds. A matrilineal European participation in Zebu cattle since its introduction to American lands has been reported. This genetic hybridization is confirmed by the significant contribution of B. primigenius taurus mtDNA to these animals. According to Meirelles et al. (1999) the two mitochondrial lineages found in American Zebu come from the introduction and establishment of Zebu breeds in America at the end of the XIX century. The importation of approximately 7000 animals from India to the Americas by Brazilian breeders and 800,000 animals from Europe during the same period (Magnabosco, 1997) can explain the observed pattern of genetic contribution of taurine cattle to American Zebu breeds.

Nellore is responsible for the majority of the Brazilian tropical herd. These animals are notably capable of enduring parasite infection as well as hot weather and low-quality feed. On one hand, these qualities suggest the large-scale application of this breed, but on other 
hand, this same breed is well characterized as being a poor food converter and consequently gains weight slowly compared with its $B$. primigenius taurus homologues.

Taurindicine hybridization of bovine populations has been described based on $\mathrm{mtD}$ NA, satellite and microsatellite allelic distribution (Nijman et al., 1999; Loftus et al., 1999). MacHugh et al. (1997) and Hanotte et al. (1997) related the presence of specific loci (ETH225, ILSTS005 and HEL1) and alleles from African and Indian Zebu breeds when compared with European breeds. The estimated participation of B. primigenius taurus in African Zebu populations ranged from 17 to $40 \%$ according to MacHugh et al. (1997). The distribution of allele frequencies of ETH225 between taurine and Zebu populations was also described by Hall and Bradley (1995). Alleles with high molecular weight were more frequent in Zebu animals while taurine animals exhibited low weight. In our study, using the same microsatellite locus (ETH225) significant differences were not found between Nellore groups (taurine and Zebu mtDNA) but the higher frequency of 159 and $161 \mathrm{bp}$ was also observed in both groups. For all microsatellites analyzed and using a similar methodology described by MacHugh et al. (1997) we found a hybridization degree of around 14\%, which represents a 7/8 crossbred. Although with low values of hybridization, this preliminary estimate is consistent with the appearance of the typical Zebu phenotype of Brazilian Nellore.

The centromeric $1711 \mathrm{~b}$ satellite DNA is an excellent marker for estimating the level of hybridization because of the dynamic of recombination and the high number of copies (Stephan, 1986). The $1711 \mathrm{~b}$ satellite DNA used in this study represents $7.1 \%$ of the bovine genome (Macaya et al., 1978). No specific taurus alleles were found in the present study. However, Zebu polymorphism due to a C/T mutation at position 524 helped us to estimate the level of hybridization identified by microsatellite data. All European animals analyzed showed only the same B restriction pattern and thus the A pattern could be assumed to be Zebu-specific. When we analyzed the frequencies of the $\mathrm{B}$ restriction pattern, present in all B. primigenius taurus, we found that Nellore harboring taurus mtDNA showed higher frequency of this pattern compared with Nellore harboring indicus mtDNA (Figure 3). This finding corroborates the microsatellite data, showing a difference of around $6 \%$ between the Zebu-specific restriction pattern when compared to Nellore indicus and taurus mtDNA.

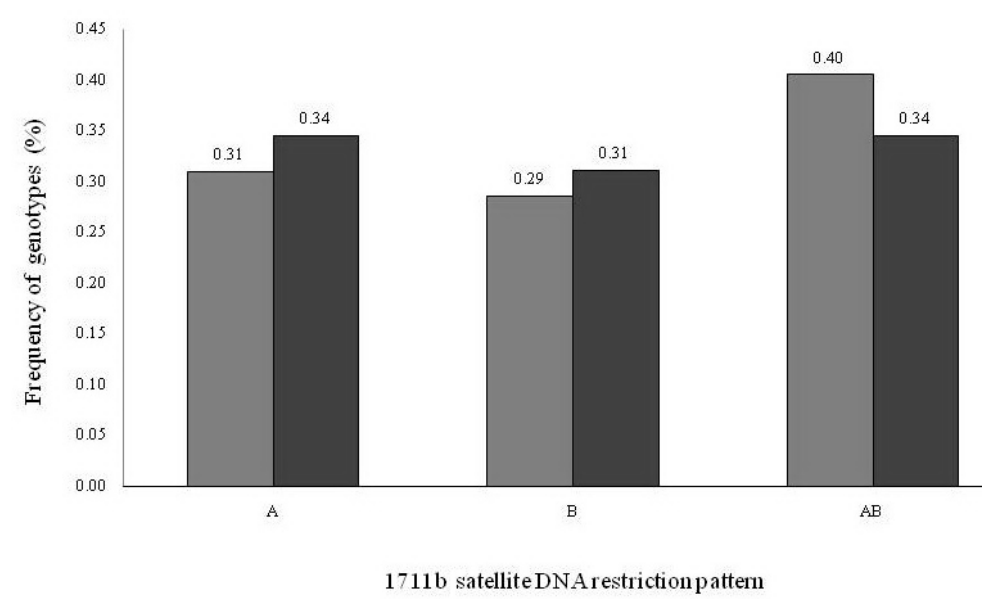

Figure 3. Frequency of $M s p \mathrm{I}$ restriction sites of $1711 \mathrm{~b}$ satellite DNA in Nellore taurus and indicus mtDNA samples. Bos taurus mtDNA (light bars) and B. indicus mtDNA (dark bars). A, B, AB = restriction patterns. 


\section{CONCLUSION}

In conclusion, we demonstrated that microsatellite and satellite markers are very informative and suitable for studying different populations, as here with Zebu and taurine cattle. The molecular marker estimate made herein, although preliminary, suggests a genetic hybridization, or taurindicine hybridization, of between 6 and 14\%, consistent with the animal's phenotype. Further studies applying the new SNP technologies will certainly help to clarify this issue.

\section{ACKNOWLEDGMENTS}

The authors would like to thank Dr. Luiz Lehmann Coutinho and Lilian Giotto Zaros for $1711 \mathrm{~b}$ satellite DNA sequencing, Dr. Raysildo Lôbo and Reginaldo Villa for POI DNA samples and technical assistance, the Roslin Institute, Edinburgh, Scotland, UK, and Dr. Maria Cristina Cabral Garcia for providing standard DNAs, Dr. Arnaldo Landgraff for the European samples and Fundação de Amparo à Pesquisa do Estado de São Paulo (FAPESP) for financial support.

\section{REFERENCES}

Anderson S, de Bruijn MH, Coulson AR, Eperon IC, et al. (1982). Complete sequence of bovine mitochondrial DNA. Conserved features of the mammalian mitochondrial genome. J. Mol. Biol. 156: 683-717.

Bradley DG and Cunningham EP (1999). Genetic Aspects of Domestication. In: The Genetics of Cattle (Fries R and Ruvinsky A, eds.). CABI Publishing, Wallingford, 15-31.

Bradley DG, MacHugh DE, Cunningham P and Loftus RT (1996). Mitochondrial diversity and the origins of African and European cattle. Proc. Natl. Acad. Sci. U. S. A. 93: 5131-5135.

Bradley DG, Loftus RT, Cunningham EP and Machugh DE (1998). Genetic and domestic cattle origins. Evol. Anthr. 6: 79-86.

Brezinsky L, Kemp SJ and Teale AJ (1993). ILSTS006: a polymorphic bovine microsatellite. Anim. Genet. 24: 73.

Chakraborty R (1985). A note on the calculation of random RP and its sampling variance. Hum. Biol. 57: 713-717.

Edwards CJ, Gaillard C, Bradley DG and MacHugh DE (2000). Y-specific microsatellite polymorphisms in a range of bovid species. Anim. Genet. 31: 127-130.

Hall SJ and Bradley DG (1995). Conserving livestock breed biodiversity. Trends Ecol. Evol. 10: 267-270.

Hanotte O, Okomo M, Verjee Y, Rege E, et al. (1997). A polymorphic Y chromosome microsatellite locus in cattle. Anim. Genet. 28: 318-319.

Hanotte O, Tawah CL, Bradley DG, Okomo M, et al. (2000). Geographic distribution and frequency of a taurine Bos taurus and an indicine Bos indicus Y specific allele amongst sub-saharan African cattle breeds. Mol. Ecol. 9: $387-$ 396.

Ibeagha-Awemu EM, Jann OC, Weimann C and Erhardt G (2004). Genetic diversity, introgression and relationships among West/Central African cattle breeds. Genet. Sel. Evol. 36: 673-690.

Kaukinen J and Varvio SL (1993). Eight polymorphic bovine microsatellites. Anim. Genet. 24: 148.

Kieffer NM and Cartwright TC (1968). Sex chromosome polymorphism in domestic cattle. J. Hered. 59: 34-36.

Liu WS, Beattie CW and Ponce de Leon FA (2003). Bovine Y chromosome microsatellite polymorphisms. Cytogenet. Genome Res. 102: 53-58.

Loftus RT, MacHugh DE, Bradley DG, Sharp PM, et al. (1994a). Evidence for two independent domestications of cattle. Proc. Natl. Acad. Sci. U. S. A. 91: 2757-2761.

Loftus RT, MacHugh DE, Ngere LO, Balain DS, et al. (1994b). Mitochondrial genetic variation in European, African and Indian cattle populations. Anim. Genet. 25: 265-271.

Loftus RT, Ertugrul O, Harba AH, El-Barody MA, et al. (1999). A microsatellite survey of cattle from a centre of origin: the Near East. Mol. Ecol. 8: 2015-2022.

Macaya G, Cortadas J and Bernardi G (1978). An analysis of the bovine genome by density-gradient centrifugation. 
Preparation of the $\mathrm{dG}+\mathrm{dC}-$ rich DNA components. Eur. J. Biochem. 84: 179-188.

MacHugh DE, Shriver MD, Loftus RT, Cunningham P, et al. (1997). Microsatellite DNA variation and the evolution, domestication and phylogeography of taurine and zebu cattle (Bos taurus and Bos indicus). Genetics 146: 1071-1086.

Magnabosco CDU (1997). Estimativas de Parâmetros Genéticos em Características de Crescimento de Animais da Raça Nelore Usando os Métodos de Máxima Verossimilhança Restrita e Amostragem Gibbs. Doctoral thesis, Faculdade de Medicina de Ribeirão Preto, USP, Ribeirão Preto.

Mannen H, Kohno M, Nagata Y, Tsuji S, et al. (2004). Independent mitochondrial origin and historical genetic differentiation in North Eastern Asian cattle. Mol. Phylogenet. Evol. 32: 539-544.

Manwell C and Baker CM (1980). Chemical classification of cattle. 2. Phylogenetic tree and specific status of the Zebu. Anim. Blood Groups Biochem. Genet. 11: 151-162.

Meirelles FV, Rosa AJM, Lôbo RB and Garcia JM (1999). Is the American Zebu is really Bos indicus? Genet. Mol. Biol. 22: 543-547.

Nei M (1987). Molecular Evolutionary Genetics. Columbia University Press, New York.

Nelder JA and Wedderburn RWM (1972). Generalized linear models. J. R. Stat. Soc. Ser. A. Gen. 135: 370-384.

Nijman IJ and Lenstra JA (2001). Mutation and recombination in cattle satellite DNA: a feedback model for the evolution of satellite DNA repeats. J. Mol. Evol. 52: 361-371.

Nijman IJ, Bradley DG, Hanotte O, Otsen M, et al. (1999). Satellite DNA polymorphisms and AFLP correlate with Bos indicus-taurus hybridization. Anim. Genet. 30: 265-273.

Raymond M and Rousset (1995). GENEPOP (version 3.1b). A population genetics software for exact tests and ecumenosm. J. Hered. 86: 248-249.

Roslin Institute (2001). Standard DNA from Taurine Breeds. Available at [http://www.projects.roslin.ac.uk]. Accessed September 14, 2002.

Sambrook J and Russell DW (2001). Molecular Cloning: A Laboratory Manual. Cold Spring Harbor Laboratory Press, Cold Spring Harbor.

SAS Institute (2004). User's Guide: Statistics. SAS Institute Inc., Cary.

Steffen P, Eggen A, Dietz AB, Womack JE, et al. (1993). Isolation and mapping of polymorphic microsatellites in cattle. Anim. Genet. 24: 121-124.

Stephan W (1986). Recombination and the evolution of satellite DNA. Genet. Res. 47: 167-174.

Streeck RE (1982). A multicopy insertion sequence in the bovine genome with structural homology to the long terminal repeats of retroviruses. Nature 298: 767-769.

Vaiman D, Mercier D, Moazami-Goudarzi K, Eggen A, et al. (1994). A set of 99 cattle microsatellites: characterization, synteny mapping, and polymorphism. Mamm. Genome 5: 288-297. 